\title{
Effects of Ammonium Carbonate Post Treatment on Phenolic Resin Treated Sesenduk (Endospermum diadenum) Wood
}

(Kesan Pasca Rawatan Amonium Karbonat terhadap Kayu Sesenduk (Endospermum diadenum) yang Dirawat dengan Resin Fenolik)

\section{ZAIDON ASHAARI*, LEE SENG HUA \& MOHD NOR EFFENDI BIN RADZALI}

\begin{abstract}
The bulking treatment with phenolic resin is well known as a treatment to improve the properties of low density wood but high amount of formaldehyde emission will be released during and after treatment. A study was conducted to determine the performance of phenolic resin treated sesenduk (Endospermum diadenum) wood post treated with ammonium carbonate and urea. Wood strips were treated separately with $30 \%$ low molecular weight phenol formaldehyde resin (LmwPF) resin and mixture of LmwPF with urea (30\% based on solid PF) using empty-cell process. Two products were produced from the treatment, i.e. impreg and compreg. After conditioning, the surfaces of the samples were applied with ammonium carbonate solution at 10,20 and $30 \mathrm{~g} / \mathrm{m}^{2}$. The samples were then stacked and stored at $60^{\circ} \mathrm{C}$ for $48 \mathrm{~h}$. Properties such as formaldehyde emission, strength and dimensional stability were evaluated. The results showed that the post treatment with ammonium carbonate has successfully reduced the formaldehyde emission from the sesenduk wood. The degree of reduction was depended on the amount of ammonium carbonate applied on the samples. The results also showed that the sesenduk wood treated with mixture of PF and urea had lower formaldehyde emission. Post treatment with ammonium carbonate did not significantly affect the physical and mechanical properties of the sesenduk wood.
\end{abstract}

Keywords: Ammonium carbonate; compreg; formaldehyde emission; impreg; sesenduk

ABSTRAK

Rawatan pukal dengan fenolik resin dikenali sebagai rawatan untuk meningkatkan kualiti kayu berketumpatan rendah tetapi jumlah formaldehid yang tinggi akan dibebaskan semasa dan selepas rawatan. Suatu kajian telah dijalankan untuk menentukan prestasi kayu sesenduk (Endospermum diadenum) yang dirawat dengan fenolik resin selepas disapu dengan amonium karbonat dan urea. Jejalur kayu telah dirawat dengan 30\% resin formaldehid fenol berat molekul rendah (LmwPF) dan juga campuran LmwPF dengan urea (30\% berdasarkan PF pepejal) secara berasingan dengan menggunakan proses sel-kosong. Dua produk terhasil daripada rawatan ini iaitu impreg dan compreg. Selepas penyamanan, permukaan sampel akan disapu dengan campuran amonium karbonat pada kadar 10, 20 dan $30 \mathrm{~g} / \mathrm{m}^{2}$. Ia kemudian disusun dan disimpan pada $60^{\circ} \mathrm{C}$ selama 48 jam. Sifat yang dinilai adalah perlepasan formaldehid, kekuatan dan kestabilan dimensi. Keputusan menunjukkan bahawa perlepasan formaldehid telah dikurangkan selepas dirawat dengan amonium karbonat. Kadar pengurangan adalah bergantung kepada jumlah penggunaan amonium karbonat pada sampel. Keputusan juga menunjukkan kayu sesenduk yang dirawat dengan campuran PF dan urea mempunyai perlepasan formaldehid yang kurang daripada kayu sesenduk yang dirawat dengan PF sahaja. Rawatan dengan amonium karbonat tidak mengubah sifat fizikal and mekanik kayu sesenduk dengan ketara.

Kata kunci: Amonium karbonat; compreg; impreg; perlepasan formaldehid; sesenduk

\section{INTRODUCTION}

In order to reduce the dependency on raw material purely from natural forests, the wood manufacturers were seeking alternative to substitute high density timber with medium or low density species such as Rubberwood and Mahang from the plantation (H'ng et al. 2012; Loh et al. 2010). Nevertheless, demand for Rubberwood timber has continued to increase while the total area replanted in rubber has been decreasing (Norini 2001), with the predicted result being a shortage of round logs for downstream processors in Rubberwood based industries. When the supply of traditional and popular Rubberwood is declining, utilising an alternative raw materials such as 'lesser known species' (LKS) would promise the sustainability future for wood-based industry.

The 'lesser known species' (LKS) in the secondary forest such as sesenduk (Endospermum diadenum) has a high potential as alternative to replace the shortage of high quality timber. However, sesenduk species usually has low density, poor dimensional stability and low mechanical strength. Sesenduk fall into the category of light hardwood $\left(385-655 \mathrm{~kg} / \mathrm{m}^{3}\right)$. This species is low in density compared with the other commercial wood and hence treatments and compression should be carried out in order to enhance the 
poor physical and mechanical properties. Fortunately, sesenduk is extremely easy to be treated with chemicals and it has excellent working properties.

The bulking treatment with phenol formaldehyde ( $\mathrm{PF})$ is a potential way of wood treatment in order to improve low physical and mechanical properties possessed by sesenduk wood. Impregnation with PF followed by curing under heat has increased the mechanical strength, dimensional stability and durability of woods against decay and termite (Ang et al. 2014). This product is known as impreg (Rowell 2005). Impregnation followed by compressing at high temperature, called compreg, has been proven in enhancing the bending strength and dimensional stability against fungal attack (Zaidon et al. 2010). However, the main concern of a wood product treated with phenol formaldehyde is that high amount of formaldehyde has been released.

Formaldehyde is classified as 'carcinogenic to humans (Group 1)' based on sufficient evidence of carcinogenicity in humans and in experimental animals (IARC 2004). The major routes of exposure to formaldehyde are by inhalation of vapour or by dermal contact with splashes of formaldehyde solutions. Indoor exposure in enclosed areas such as residential houses and educational facilities, called 'Sick House Syndrome', has been detected in Japan causing headache and nose and throat irritation among users. The major effects following a critical inhalation exposure to formaldehyde is irritation and burning of the mucous membranes of the nose, mouth and upper respiratory tract (IPCS 1989). The release of formaldehyde from formaldehyde-based adhesive bonded particleboard is caused by two factors. It can be due to free formaldehyde present in the board that has not reacted, and it can be due to formaldehyde formed by hydrolysis of the aminoplastic bond as a result of temperature and relative humidity (Marutzky 1989; Pizzi 1983). While the first type of release lasts only a short time after manufacture of the particleboard, the second type of release can continue throughout the entire working life of the board.

Due to the issues that caused by formaldehyde emission, regulations in reducing formaldehyde emissions from wood and wood-based products had been issued by many countries and several methods had been identified as effective way to reduce formaldehyde emission. The most notable method for reducing formaldehyde emission from wood and wood-based products is using formaldehyde scavenger. Formaldehyde scavenger is a chemical that can bond free formaldehyde and can be used either on post treatment and incorporating into the resin during mixing process. Formaldehyde scavenger can be applied in two methods; treatment after conditioning (denoted as post treatment) and incorporating in the resin during glue mixing (denoted as add-in). Post treatment normally applied the catcher on the surface of produced particleboard and this might influence the surface characteristic of the panel. The formaldehyde scavenger normally contains urea and ammonium salt. Thus, post treating sesenduk wood with ammonium carbonate is another potential method to reduce formaldehyde emission (Westling et al. 1984).

Besides, urea has long been recognised as a potential scavenger that can be introduced into the resin system to bring down formaldehyde emission (Rabi'atol Adawiah et al. 2012). A study therefore was conducted to investigate the effect of ammonium carbonate post treatment on formaldehyde emission of sesenduk wood impregnated and compregnated with low molecular weight phenol formaldehyde (LmwPF) in comparison to the application of urea. This study also assessed both mechanical and physical strength of the phenolic resin treated sesenduk wood as function of ammonium carbonate dosage and urea concentration.

\section{MATERIALS AND METHODS}

\section{PREPARATION OF MATERIALS}

Sesenduk woods (Endospermum diadenum) used in this study were obtained from Forest Research Institute Malaysia (FRIM). Air dried sesenduk woods were cut into wood strips with dimension of $200 \mathrm{~mm}$ long $\times 45$ $\mathrm{mm}$ wide $\times 10 \mathrm{~mm}$ thick. Cut samples were conditioned in conditioning room at a temperature of $25 \pm 2^{\circ} \mathrm{C}$ and a relative humidity of $65 \pm 2 \%$. Low molecular weight phenol formaldehyde (LmwPF, mw 600) resin with solid content of $45 \%$ was used as treating solution in this study. This phenol formaldehyde resin was specially synthesised at Malayan Adhesives and Chemical (MAC) Sdn. Bhd., Shah Alam. Urea which was obtained from MAC was incorporated into the resin to act as formaldehyde scavenger. Two treating solutions were prepared for this study which is solution with pure LmwPF (30\% w/v) and solution of 30\% LmwPF with $30 \%$ urea ( $30 \%$ based on solid PF). The experimental design of the study is shown in Table 1.

\section{IMPREGNATION AND COMPREGNATION PROCESS}

Impregnation process was carried out separately by impregnate the wood strips with different treating solutions. The pressure treatment process began with the strips placed in a vacuum-pressure apparatus filled with the treating solution. The wood strips were fully submerged in the resin solution. Empty cell process (Lowry process) was used to treat the wood. A $690 \mathrm{kPa}$ of external pressure applied to the vacuum-pressure apparatus for $1 \mathrm{~h}$. Once the treatment was completed, the pressure was released and the samples were taken out and then wiped with cloth to remove excessive resin. The treated samples were then pre-cured in the oven at a temperature of $65 \pm 2^{\circ} \mathrm{C}$ for $6 \mathrm{~h}$. The dimension and weight of the treated samples were measured before and after precuring in oven. For compregnation, after the impregnation process, the samples were compressed under hot press at $150^{\circ} \mathrm{C}$ for $30 \mathrm{~min}$ to achieve $40 \%$ compression ratio (CR). A set of $4 \mathrm{~mm}$ stopper bar was used to control the 
TABLE 1. Experimental design of the study

\begin{tabular}{|c|c|c|c|}
\hline Treatment & Treatment process & $\begin{array}{l}\text { Urea conc. } \\
\qquad(\%)\end{array}$ & $\begin{array}{l}\text { Ammomuin carbonate dosage } \\
\qquad\left(\mathrm{g} / \mathrm{m}^{2}\right)\end{array}$ \\
\hline $\mathrm{T} 1$ & $\begin{array}{l}\text { Inpregnation with } 30 \% \mathrm{LmwPF} \text {, followed by } \\
\text { curing in oven at } 150^{\circ} \mathrm{C} \text { (Impreg) }\end{array}$ & 0 & $10,20,30$ \\
\hline $\mathrm{T} 2$ & $\begin{array}{l}\text { Inpregnation with } 30 \% \mathrm{LmwPF} \text {, followed by } \\
\text { curing in oven at } 150^{\circ} \mathrm{C} \text { (Impreg) }\end{array}$ & 30 & $10,20,30$ \\
\hline $\mathrm{T} 3$ & $\begin{array}{l}\text { Compregnation with } 30 \% \mathrm{LmwPF} \text {, followed by } \\
\text { compressing in hot press at } 150^{\circ} \mathrm{C} \text { (compreg) }\end{array}$ & 0 & $10,20,30$ \\
\hline $\mathrm{T} 4$ & $\begin{array}{l}\text { Compregnation with } 30 \% \mathrm{LmwPF} \text {, followed by } \\
\text { compressing in hot press at } 150^{\circ} \mathrm{C} \text { (compreg) }\end{array}$ & 30 & $10,20,30$ \\
\hline
\end{tabular}

final thickness. The compression ratio was calculated using Equation 1:

$$
\mathrm{CR}(\%)=\left(\mathrm{T}_{\mathrm{f}} / \mathrm{T}_{\mathrm{i}}\right) \times 100,
$$

where $T_{f}$ is the final thickness after compress ( $\mathrm{mm}$ ) and $\mathrm{T}_{\mathrm{i}}$ is the initial thickness ( $\mathrm{mm})$.

The compreg samples were then conditioned in conditioning room at a temperature of $25 \pm 2^{\circ} \mathrm{C}$ and a relative humidity of $65 \pm 2 \%$ until the constant weight was achieved prior to properties evaluation.

\section{POST TREATMENT WITH AMMONIUM CARBONATE}

Post treatment with aqueous ammonium carbonate was applied to the samples using brushing technique. 10, 20 and $30 \mathrm{~g} / \mathrm{m}^{2}$ of ammonium carbonate (dry salt) were weighed and dissolved in $10 \mathrm{ml}$ of distilled water, respectively. The treated woods were brushed with aqueous ammonium carbonate and were stacked and stored in oven for $48 \mathrm{~h}$ at a temperature of $60^{\circ} \mathrm{C}$.

\section{EVALUATION OF MECHANICAL PROPERTIES}

The mechanical properties such as modulus of rupture (MOR) and modulus of elasticity (MOE) were performed according to British Standard BS 373:1957 (BSI 1957) with a modification of sample size. Test samples with dimension of $200 \mathrm{~mm}$ long $\times 45 \mathrm{~mm}$ wide $\times 10 \mathrm{~mm}$ thick were tested using universal testing machine (Instron 50 $\mathrm{kN}$ ). The centre loading was applied at a span length of $120 \mathrm{~mm}$. Static bending was tested by applying a load of approximately $0.50 \mathrm{~mm} / \mathrm{min}$ at a mean deformation speed from the surface of the test piece, and the maximum load will be measured. The MOR and MOE were calculated based on the formula below:

$$
\begin{aligned}
& \operatorname{MOE}\left(\mathrm{Nmm}^{-2}\right)=3 \mathrm{P}_{\mathrm{m}} \mathrm{L}^{3} / 2 \mathrm{wh}^{2}, \\
& \operatorname{MOR}\left(\mathrm{Nmm}^{-2}\right)=\mathrm{P}_{1} \mathrm{~L}^{3} / 4 \mathrm{Dwh} h^{3},
\end{aligned}
$$

where $\mathrm{P}_{\mathrm{m}}$ is the maximum breaking load $(\mathrm{N}), \mathrm{P}_{1}$ is the load at proportional limit $(\mathrm{N}), \mathrm{L}$ is the span of the test samples $(\mathrm{mm}), \mathrm{D}$ is the deflection at mid-span resulting from $\mathrm{P}_{1}$ $(\mathrm{mm}), \mathrm{w}$ is the width of the test samples $(\mathrm{mm})$ and $\mathrm{h}$ is the height of the test samples ( $\mathrm{mm})$.

\section{EVALUATION OF PHYSICAL PROPERTIES}

Thickness swelling (TS) and water absorption (WA) test were carried out by vacuum-soaking method in distilled water. Five samples with nominal size of $20 \mathrm{~mm}$ wide and $20 \mathrm{~mm}$ long and $10 \mathrm{~mm}$ thick were prepared. Thickness and weight of the samples were measured and weighted before submerge in water. Treated and untreated samples were submerged in distilled water in a beaker. The beaker with the content was placed in a vacuum pressure apparatus and vacuum for $30 \mathrm{~min}$. They were left soaked in the water under atmospheric pressure for $24 \mathrm{~h}$. Then, the test samples were taken out and wiped off the water and the thickness and weight were measured again. The test of swelling in thickness (TS) and water absorption (WA) after immersion in water will be calculated by using formula as below:

$$
\begin{aligned}
& \text { TS }(\%)=\left(\mathrm{T}_{2}-\mathrm{T}_{1}\right) / \mathrm{T}_{1} \times 100, \\
& \mathrm{WA}(\%)=\left(\mathrm{W}_{2}-\mathrm{W}_{1}\right) / \mathrm{W}_{1} \times 100,
\end{aligned}
$$

where $T_{1}$ is the thickness of samples before immersion in water $(\mathrm{mm}), \mathrm{T}_{2}$ is the thickness of samples after immersion in water $(\mathrm{mm}), \mathrm{W}_{1}$ is the weight of samples before immersion in water $(\mathrm{mm})$ and $\mathrm{W}_{2}$ is the weight of samples after immersion in water $(\mathrm{mm})$.

\section{FORMALDEHYDE EMISSION TEST}

Formaldehyde emission of treated samples was conducted in accordance with Malaysian Standards (MS 2005). A calibration curve was first produced from a standard formaldehyde solution by iodometric titration. A total of 8 pieces with approximately $1800 \mathrm{~cm}^{2}$ total surface areas were put in a desiccator having $300 \mathrm{~mL}$ of distilled water and kept for $24 \mathrm{~h}$ at a temperature of $20 \pm 2^{\circ} \mathrm{C}$ and $65 \pm 5 \%$ relative humidity. The background formaldehyde was prepared using a desiccator containing no test samples. Formaldehyde absorbance in water was measured photometrically at $412 \mathrm{~nm}$ wavelength. The concentration 
of formaldehyde was determined using the following equation:

$$
G=f \times\left(A_{d}-A_{b}\right) \times 1800 / S
$$

where $\mathrm{G}$ is the concentration of formaldehyde due to test samples $(\mathrm{mg} / \mathrm{L}), \mathrm{A}_{\mathrm{d}}$ is the absorbance of the solution from the desiccator containing the test samples, $A_{b}$ is the absorbance of the background formaldehyde solution, $\mathrm{f}$ is the slope of the calibration curve for the standard formaldehyde solution and $\mathrm{S}$ is the surface area of the test samples $\left(\mathrm{cm}^{2}\right)$.

\section{STATISTICAL ANALYSES}

The data were analysed statistically to verify the significance of the variables in this study. The data were analysed using Statistical Package for the Social Sciences (SPSS) procedure for the analysis of variance (ANOVA) at $95 \%$ confident level ( $p \leq 0.05)$. Tukey's honest significant difference (HSD) tests were then used to further determine the significant level of average values for each treatment. Pearson's correlation coefficient tests were carried out to determine the correlations between dependent and independent variables.

\section{RESULTS AND DISCUSSION}

\section{WEIGHT PER CENT GAIN (WPG)}

Table 2 shows the weight per cent gain (WPG) of both impregnated and compregnated sesenduk wood with and without the presence of urea. WPG for the sesenduk wood impregnated with 0 and $30 \%$ of urea were 36 and $35 \%$, respectively. Meanwhile, WPG of $63 \%$ and $59 \%$ were recorded in the sesenduk wood compregnated with 0 and $30 \%$ concentration of urea, respectively. Gain in weight is expected as the resin penetrated into the wood lumen and cell wall. However, sesenduk wood treated without the presence of urea had relatively higher WPG compared with that of the sesenduk wood treated with the presence of urea. This phenomenon might be caused by the presence of methylolated urea in the PF resin. The addition of urea to the LmwPF prior to resin impregnation can induce reaction between urea and free formaldehyde in the system to methylolated urea which does not react further under alkaline condition. Thus, the presence of methylolated urea may have increased the viscosity of the resin solution, thereby, limiting the penetration into the cell wall and lumen of the wood and subsequently lead to lower WPG (Rabi'atol Adawiah et al. 2012).

\section{EFFECTS OF AMMONIUM CARBONATE ON FORMALDEHYDE EMISSION OF SESENDUK WOOD}

Calibration curve from iodometric titration is illustrated in Figure 1. This graph has estimated slope which is used in determination of formaldehyde emission of the samples. The slope obtained was $9.089 \times-0.155$ with $r^{2}=0.997$. Regardless of urea addition, post treatment using ammonium carbonate $\left(\left(\mathrm{NH}_{4}\right)_{2} \mathrm{CO}_{3}\right)$ had reduced the formaldehyde emission of treated sesenduk wood. Figure 2 illustrates the formaldehyde emission of both impregnated and compregnated sesenduk wood. From Figure 2, one can see that the formaldehyde emission values of sesenduk wood impregnated with 30\% LmwPF ranged from 18.28 to $21.89 \mathrm{mg} / \mathrm{L}$. In the meantime, formaldehyde emission values of the sesenduk impregnated with admixture of $30 \% \mathrm{LmwPF}$ and $30 \%$ urea ranged from 4.67 to $8.12 \mathrm{mg} / \mathrm{L}$. From the result obtained, a decrement of approximately $75 \%$ in formaldehyde emission was observed when $30 \%$ of urea was incorporated in LmwPF. On the contrary, around $43 \%$ reductions in formaldehyde emission were recorded when the dosage of ammonium carbonate was increased while the urea concentration remained constant. On the other hand, the same pattern of results was observed in the compreg wood. Formaldehyde emission of the compreg sesenduk wood reduced approximately $78 \%$ when $30 \%$ of urea was added. When the urea concentration remained constant, increased in ammonium carbonate dosage reduced the formaldehyde emission as much as $35 \%$.

Table 3 summarises the correlation between the dependent (formaldehyde emission) and independents (ammonium carbonate dosage and urea concentration). Negative and significant correlation was found between urea and formaldehyde emission $(r=-0.978)$. This phenomenon indicating that urea had successfully absorbed some of the free formaldehyde in the resin system and formed crosslinked polymer of urea formaldehyde (Hoong et al. 2010). On the contrary, negative but not significant correlation was found between ammonium carbonate dosage and formaldehyde emission. Although the magnitude of reduction in formaldehyde emission was not as strong as urea, formaldehyde emission of sesenduk wood was further reduced when treated using ammonium carbonate. The reduction of formaldehyde emission

TABLE 2. Weight percent gain of treated sesenduk wood

\begin{tabular}{cccc}
\hline Treatment & Treatment method & Urea concentration $(\%)$ & Weight percent gain $(\%)$ \\
\hline T1 & Impreg & 0 & $35.96 \pm 8.83$ \\
T2 & Impreg & 30 & $35.08 \pm 7.53$ \\
T3 & Compreg & 0 & $62.88 \pm 15.87$ \\
T4 & Compreg & 30 & $58.75 \pm 16.44$ \\
\hline
\end{tabular}

* Values after \pm are standard deviation 


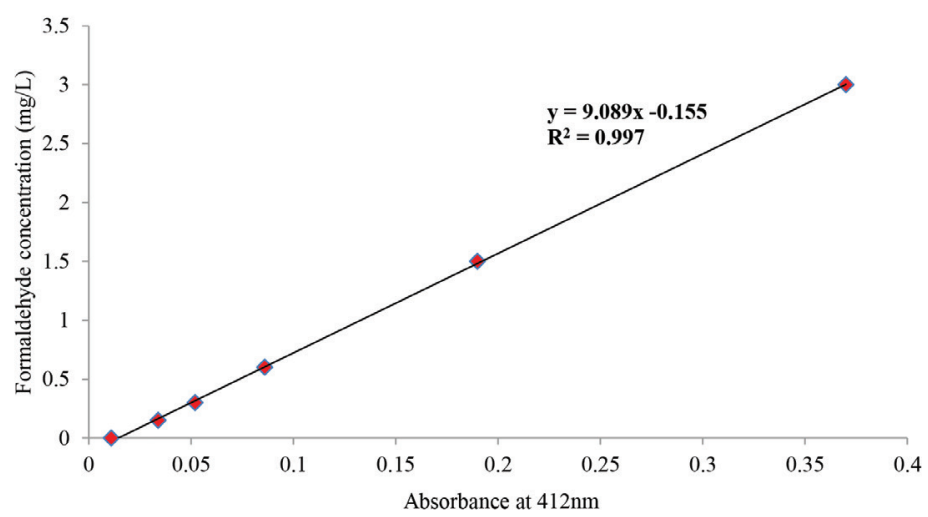

FIGURE 1. Calibration curve of standard formaldehyde concentration vs absorbance using spectrophotometer

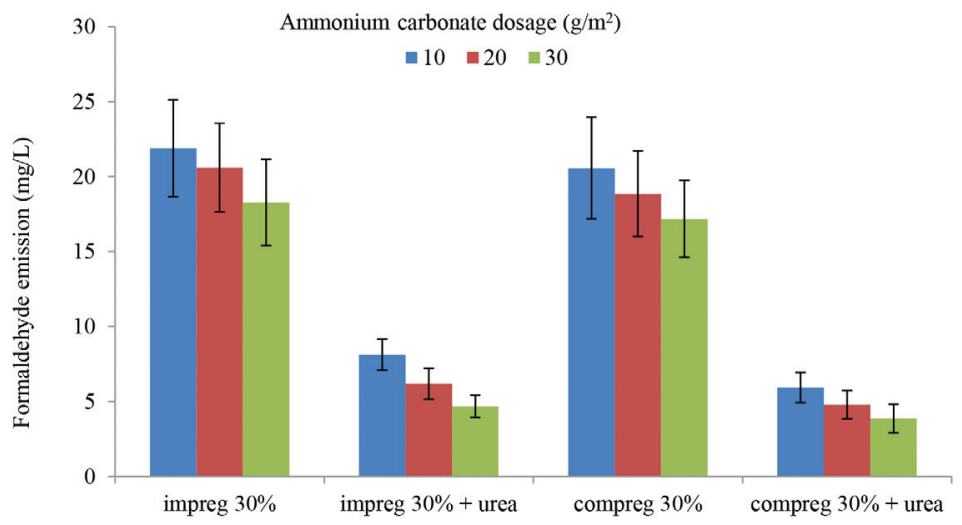

FIGURE 2. Formaldehyde emission values of the treated sesenduk wood

TABLE 3. Correlation between formaldehyde emission and independent variables

\begin{tabular}{llc}
\hline & Ratio & Formaldehyde emission \\
\hline$\left(\mathrm{NH}_{4}\right)_{2} \mathrm{CO}_{3}$ & Pearson Correlation & -0.179 \\
& Sig. (2-tailed) & 0.171 \\
Urea & Pearson Correlation & $-0.978^{* *}$ \\
& Sig. (2-tailed) & 0.000 \\
\hline
\end{tabular}

**significant at $95 \%$ confident level $(p \leq 0.05)$

increased with the increasing dosage of ammonium carbonate used. The possible theory of the reduction of formaldehyde emission is shown in the equations as follows:-

Ammonium carbonate can spontaneously decompose into ammonium bicarbonate and ammonia at standard temperature and pressure (a temperature of $273.15 \mathrm{~K}$ and an absolute pressure of $100.00 \mathrm{kPa}$ ) as the following reaction:

$$
\left(\mathrm{NH}_{4}\right)_{2} \mathrm{CO}_{3} \rightarrow \mathrm{NH}_{4} \mathrm{HCO}_{3}+\mathrm{NH}_{3} \text {. }
$$

Ammonium bicarbonate $\left(\mathrm{NH}_{4} \mathrm{HCO}_{3}\right)$ will decomposes when exposed to $36^{\circ} \mathrm{C}$ and above. As the sesenduk wood treated with ammonium carbonate was stacked in oven at $60^{\circ} \mathrm{C}$, ammonium bicarbonate readily decomposes into ammonia, carbon dioxide and water in an endothermic process:

$$
\mathrm{NH}_{4} \mathrm{HCO}_{3} \rightarrow \mathrm{NH}_{3}+\mathrm{H}_{2} \mathrm{O}+\mathrm{CO}_{2} \text {. }
$$

The ammonia produced was then reacted with any uncombined formaldehyde (free and/or liberated from the wood) to form hexamethylenetetramine (urotropin) as the following reaction:

$$
\begin{aligned}
& 6 \mathrm{CH}_{2} \mathrm{O}+4 \mathrm{NH}_{3} \rightarrow \mathrm{C}_{6} \mathrm{H}_{12} \mathrm{~N}_{4} \text { (hexamethylenetetramine) } \\
& +6 \mathrm{H}_{2} \mathrm{O} .
\end{aligned}
$$


By this way, the formaldehyde evolved is entrapped and hence leads to reduction in subsequent emission of formaldehyde.

\section{EFFECTS OF AMMONIUM CARBONATE ON MECHANICAL PROPERTIES OF SESENDUK WOOD}

Table 4 summarises the correlations between the dependents (MOR, MOE) and independents (ammonium carbonate dosage and urea concentration). No significant correlations were observed between mechanical properties of the treated sesenduk and ammonium carbonate dosage. Figures 3 and 4 illustrate the modulus of rupture (MOR) and modulus of elasticity (MOE) values of the treated sesenduk wood, respectively. From Figures 3 and 4, one can see that both MOR and MOE values exhibited an inconsistent pattern as the dosage of ammonium carbonate increased. These inconsistent patterns were in agreement with the
Pearson's correlation listed in Table 4, suggesting that the application of ammonium carbonate did not affect the mechanical properties of the treated sesenduk wood. This is because ammonium carbonate was merely applied on the surface of the sesenduk wood and this application would not interfere with the curing behaviour of the resin as well as the molecular weight of the resin system (Lum et al. 2014).

In addition, it is interesting to note that a significant negative correlation was observed between addition of urea and mechanical properties ( $r=-0.573$ and $r=-0.558$ for MOR and MOE, respectively). It indicates that the addition of urea into phenol formaldehyde resin lowered the mechanical properties of sesenduk woods. This may due to the presence of urea which increased the molecular weight of the resin system and hence limited the penetration of resin into cell wall of treated wood (Purba et al. 2014).

TABLE 4. Correlations between modulus of rupture (MOR) and modulus of elasticity (MOE) and independent variables

\begin{tabular}{llcc}
\hline & Ratio & MOR & MOE \\
\hline$\left(\mathrm{NH}_{4}\right)_{2} \mathrm{CO}_{3}$ & Pearson Correlation & 0.226 & -0.093 \\
& Sig. (2-tailed) & 0.082 & 0.482 \\
\multirow{2}{*}{ Urea } & Pearson Correlation & $-0.573^{* *}$ & $-0.558^{* *}$ \\
& Sig. (2-tailed) & 0.000 & 0.000 \\
\hline
\end{tabular}

**significant at $95 \%$ confident level $(p \leq 0.05)$

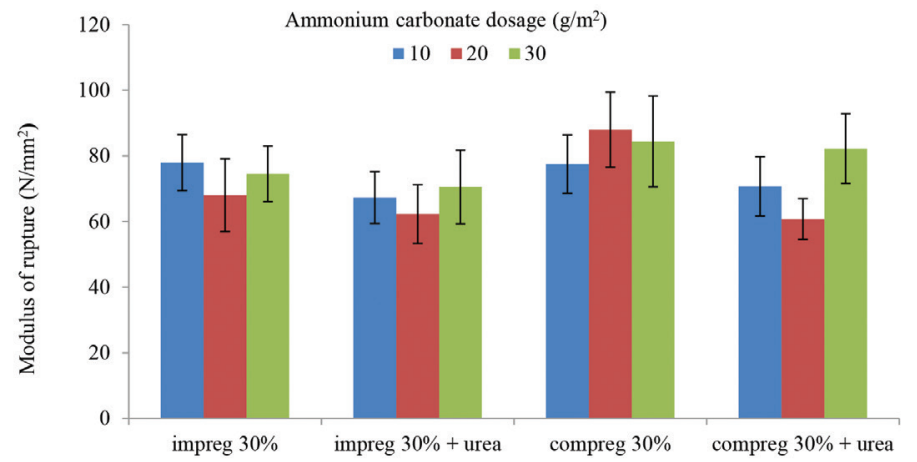

FIGURE 3. Modulus of rupture (MOR) values of the treated sesenduk wood

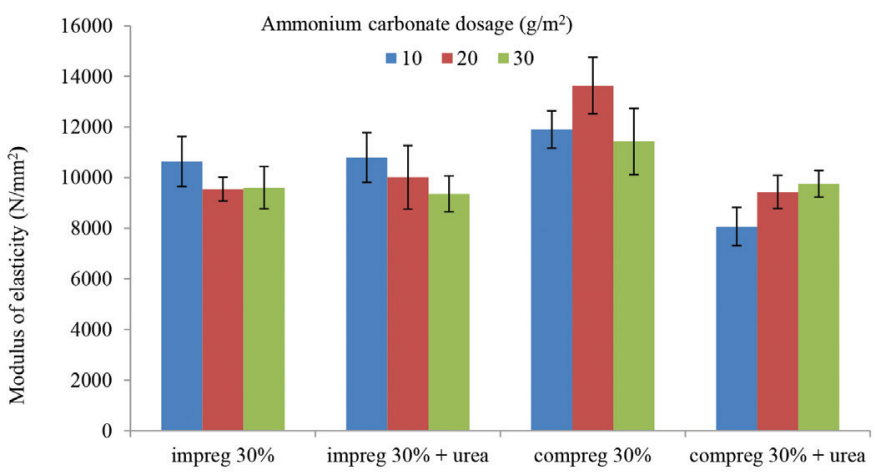

FIGURE 4. Modulus of elasticity (MOE) values of the treated sesenduk wood 
EFFECTS OF AMMONIUM CARBONATE ON PHYSICAL PROPERTIES OF SESENDUK WOOD

The changes in thickness swelling (TS) and water absorption (WA) on sesenduk wood treated with different dosages of ammonium carbonate and urea concentrations are presented in Figures 5 and 6, respectively. Table 5 summarises the correlation between the dependent (TS and WA) and independent (ammonium carbonate dosage and urea concentration). Based on Table 5, positive and significant correlation was observed between WA and ammonium carbonate dosage $(r=0.663)$ indicating that WA increased as the dosage of ammonium carbonate dosage increased. Although the correlation is not significant, a positive correlation was also found between
TS and ammonium carbonate. This might part due to the ammonium carbonate acting as hydrophilic compound for attracting the water to enter the panel (Lum et al. 2014). Application of aqueous ammonium carbonate on the surface of sesenduk wood may reduce its surface tension and increase its wettability, thus, made the wood more susceptible to take up water.

On the other hand, introduction of urea into LmwPF resin was found to increase the degree of swelling $(r=0.343)$ significantly while the WA was not significantly affected $(r=-0.035)$. The physical properties of the resinimpregnated wood highly rely on the molecular weight of the resins used. Addition of urea has increased the molecular weight of the resin system which caused it

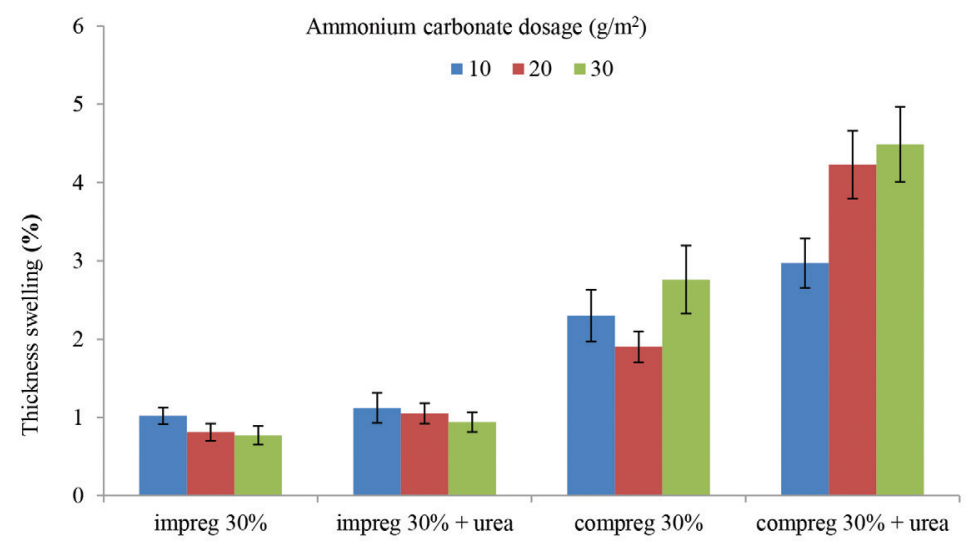

FIGURE 5. Thickness swelling (TS) values of the treated sesenduk wood

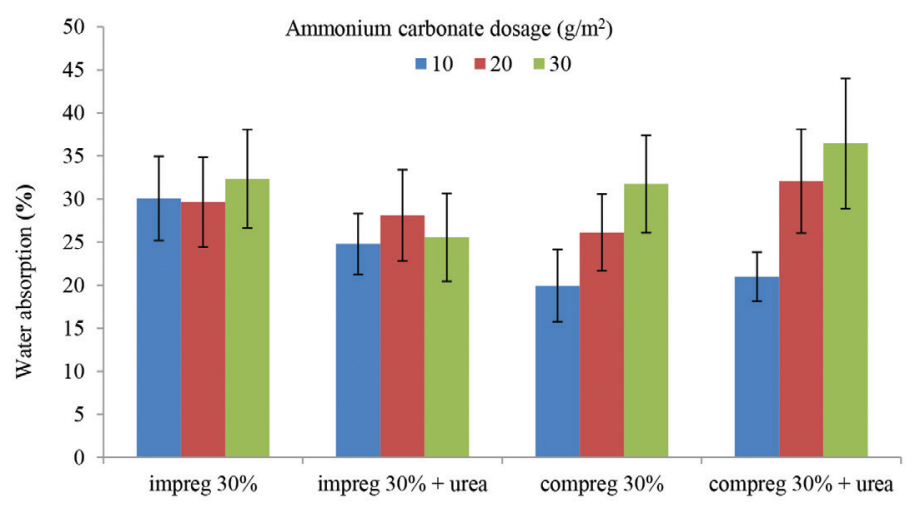

FIGURE 6. Water absorption (WA) values of the treated sesenduk wood

TABLE 5. Correlations between thickness swelling (TS) and water absorption (WA) and independent variables

\begin{tabular}{llll}
\hline & Ratio & TS & WA \\
\hline$\left(\mathrm{NH}_{4}\right)_{2} \mathrm{CO}_{3}$ & Pearson Correlation & 0.124 & $0.663^{* *}$ \\
& Sig. (2-tailed) & 0.344 & 0.000 \\
\multirow{2}{*}{ Urea } & Pearson Correlation & $0.343^{* *}$ & -0.035 \\
& Sig. (2-tailed) & 0.007 & 0.792 \\
\hline
\end{tabular}

**significant at $95 \%$ confident level $(p \leq 0.05)$ 
unable to penetrate the cell wall or, in other word, the penetration is limited. A barrier will be formed on the surface of the lumen if the molecules are too large to penetrate the cell wall. However, this only impart a short term barrier again water and moisture uptake as this barrier may be breached after some period (Hill 2006). As the barrier was breached, water penetrates into the wood cell and lead to changes in TS and WA.

\section{CONCLUSION}

Formaldehyde emission of the treated sesenduk wood (impreg and compreg) reduced significantly with the addition of urea in the phenol formaldehyde resin. Post treatment with ammonium carbonate was found further reduced the formaldehyde emission of the treated sesenduk wood. The formaldehyde emission of the treated sesenduk decreased with the increasing dosage of ammonium carbonate. In term of mechanical properties, no significant correlations were observed between mechanical properties (MOR and MOE) and ammonium carbonate dosage. However, addition of urea in the phenol formaldehyde resin somehow lowered the mechanical properties of the treated sesenduk wood. On the other hand, significant correlation was observed between WA and ammonium carbonate dosage. Application of ammonium carbonate on the surface of sesenduk wood may have alter its surface characteristic and hence increase the water uptake rate. Addition of urea to the LmwPF resin had increased the degree of swelling of the treated sesenduk wood. This study has proved that ammonium carbonate is a potential formaldehyde scavenger to bring down formaldehyde emission and did not adversely affect the properties of wood.

\section{REFERENCES}

Ang, A.F., Zaidon, A., Bakar, E.S., Mohd Hamami, S., Anwar, U.M.K. \& Jawaid, M. 2014. Possibility of improving the properties of Mahang Wood (Macaranga sp.) through phenolic compreg technique. Sains Malaysiana 43(2): 219225.

H'ng, P.S., Lee, S.H. \& Lum, W.C. 2012. Effect of post heat treatment on dimensional stability of UF bonded particleboard. Asian Journal of Applied Science 5(5): 299306.

Hill, C.A.S. 2006. Modifying the properties of wood. In Wood Modification: Chemical, Thermal and Other Processes. London: John Wiley \& Sons Ltd.

Hoong, Y.B., Paridah, M.T., Loh, Y.F., Koh, M.P., Luqman, C.A. \& Zaidon, A. 2010. Acacia mangium tannin as formaldehyde scavenger for low molecular weight phenol formaldehyde resin in bonding tropical plywood. Journal of Adhesion Technology 24: 1563-1664.
International Agency for the Research on Cancer (IARC). 2004. Formaldehyde. Vol 88. IARC. Lyon.

International Programme on Chemical Safety (IPCS). 1989. Formaldehyde. Environmental Health Criteria 89. WHO. Geneva.

Loh, Y.W., H'ng, P.S., Lee, S.H., Lum, W.C. \& Tan, C.K. 2010. Properties of particleboard produced from admixture of Rubberwood and Mahang species. Asian Journal of Applied Science 3(5): 310-316.

Lum, W.C., Lee, S.H. \& H'ng, P.S. 2014. Formaldehyde catcher on some properties of particleboard with different ratio of surface to core layer. Asian Journal of Applied Sciences 7(1): 22-29.

Marutzky, R. 1989. Wood Adhesives Chemistry and Technology. Vol. 2, edited by A. Pizzi. New York: Marcel Dekker. pp. 307-388.

Norini, H. 2001. Supply and demand of timber for the woodbased panel industries in Malaysia. In Proceedings of the 3rd National Seminar: Wood-Based Panel Products. Kuala Lumpur: Forest Research Institute Malaysia. 10-11, July.

Pizzi, A. 1983. Wood Adhesives Chemistry and Technology. Vol. 1. New York: Marcel Dekker. pp. 59-104.

Purba, T.P., Zaidon, A., Bakar, E.S. \& Paridah, M.T. 2014. Effects of processing factors and polymer retention on the performance of phenolic-treated wood. Journal of Tropical Forest Science 26(3): 320-330.

Rabi'atol Adawiah, M.A., Zaidon, A., Nur Izreen, F.A., Bakar, E.S., Mohd Hamami, S. \& Paridah, M.T. 2012. Addition of urea as formaldehyde scavenger of low molecular weight phenol formaldehyde treated compreg wood. Journal of Tropical Forest Science 24: 265-274.

Rowell, R.M. 2005. Chemical modification of wood. In Handbook of Wood Chemistry and Wood Composites, edited by Rowell, R.M. Florida: CRC Press.

Westling, A.W. 1981. A method of reducing the emission of formaldehyde from particleboard bound with carbamide resin. Europe patent application, 0027 - 583.

Zaidon,A., Bakar, E.S. \& Paridah, M.T. 2010. Compreg laminates from low density tropical hardwoods. In Proceedings of the International Convention of Society of Wood Science and Technology and United Nations Economic Commission for Europe - Timber Committee. 11-14 October. Geneva.

Faculty of Forestry

Universiti Putra Malaysia

43400 UPM Serdang, Selangor

Malaysia

*Corresponding author; email: zaidon@upm.edu.my

Received: 23 September 2014

Accepted: 16 February 2015 